\title{
The Effect of the Country-of-Origin Image, Product Knowledge and Product Involvement on Consumer Purchase Decisions
}

\author{
Khosrozadeh Shirin, Heidarzadeh Hanzaee Kambiz \\ Science and Research Branch, Islamic Azad University, Tehran, Iran
}

\begin{abstract}
This paper discusses the influence of the country-of-origin image, product knowledge and product involvement on consumer purchase decisions. Data were collected by a questionnaire from college students. Multiple regression analysis of data from 379 respondents was used to test three hypotheses. The results show that the country-of-origin image, product knowledge and product involvement all have a significantly positive effect on consumer purchase decision. Further research should examine the different dimensions of involvement and product knowledge on consumer purchase decisions.
\end{abstract}

Keywords: country-of-origin image, product knowledge, product involvement

\section{Introduction}

General Agreement on Tariff and Trade (GATT) was created in 1947. Its main goal was to keep world trade of participatory members flowing as smoothly and freely as possible. The World Trade Organization (WTO) officially commenced in 1995, replacing the General Agreement on Tariff and Trade, and it worked out to eliminate non-tariff barriers and economic problems in response to the problems identified in 1970s and 1980s. WTO operates under four principles including equality, mutual benefits, transparency, and fair trade aimed at enforcing participants to open their markets based on a profitable system and make it possible for local consumers to choose their products from both their own country's market and that of others.

Bulky commodities were imported to Iran through various channels, therefore, local consumers had chance to compare local and foreign products while shopping. Marketing researchers focus on factors which influence upon consumers' selection. This paper accordingly investigates factors impacting cell phone consumers' decision in Iran. In other words, profitable market of cell phone in Iran, and consequently huge import of this product contributed to the development of this paper. According to Kapferer and Laurent (1985), involvement impacts the general process of consumers' decision making, from initial information probe to ultimate evaluation of purchased product. However, several factors commonly affect consumers' evaluation, and brand and price are two typical examples. Moreover, globalization of products and markets add some other factors to the check list of

\footnotetext{
Khosrozadeh Shirin, MA, Department of Business Management, Science and Research Branch, Islamic Azad University. Heidarzadeh Hanzaee Kambiz, Ph.D., Associate Professor, Department of Business Management, Science and Research Branch, Islamic Azad University.

Correspondence concerning this article should be addressed to Khosrozadeh Shirin, Department of Business Management, Science and Research Branch, Islamic Azad University, Tehran, Iran. E-mail: shirinkhosrozadeh@yahoo.com.
} 
consumers including country of origin image. Papadopoulos and Heslop (1993) stated that the images of objects result from peoples' perceptions and of the phenomena that surround them. Since people act on what they believe is true, "intrinsic reality" plays a lesser role in human affairs than "perceived reality". Inevitably, the existence of images leads to the stereotyping of objects. Stereotyping is inherent to the process of classification which people use as a means of coping with the world around them. Roth and Romeo (1992) have defined the country-of-origin as stereotypical perceptions of consumers about a particular country. The country-of-origin is defined as a country which consumers ascribe the origin of a brand to, regardless of where the product was actually produced. For several decades, manufacturers, suppliers and consumers acknowledged the significance of aforementioned images. Papadopoulos and Heslop (1983) believe application of stereotypical images by vendors and purchasers makes decision making easier and in case there is a large gap between perceived reality and intrinsic reality, it works to push them closer to one another. Correct and successful decision making in marketing is subject to consumers having accurate recognition. On the other hand, product knowledge also plays an important role in consumer behavior, because at different levels of knowledge, consumers act differently. Thus, product knowledge is highlighted in the present study along with two other factors, i.e., the country-of-origin and involvement, in order to investigate their impact on cell phone's consumer purchase decisions.

Generally, the main objective of this research is threefold as follows: evaluating the impact of country-of-origin image, product knowledge, and involvement on consumer purchase decisions

\section{Literature Review}

\section{Consumer Purchase Decision}

An understanding of the contextual elements that impact upon individual purchase decision making and the overall process through which individuals behave and ultimately make decisions is an important first stage in the development of any marketing communications plan. Fill (1999), asserts that there are five stages to the general process whereby buyers make purchase decisions and implement them. Marketing communications can impact upon any or all of these stages with varying level of potential effectiveness. This process includes: problem recognition, information search, alternative evaluation, purchase decision and post-purchase evaluation. Problem recognition occurs when there is a perceived difference between an individual's ideal state and reality. Having identified a problem a prospective buyer will search for information in an attempt to resolve it. There are two main areas of search activity: (1) The internal search involves a memory scan to recall experiences and knowledge, utilizing the perceptual processes to see if there is an off-the-shelf solution; (2) If there is no off-the-shelf solution, the prospective buyer will resort to an external search. This will involve family and friends, reference sources and commercial guides and advertising. Then potential solutions need to be evaluated in order that the optimum choice is made. After that, the buyer may develop a predisposition to make a purchase. This will involve matching motives and evaluative criteria with product attributes. After the purchase decision has been made, a buyer might feel tension about a past decision either because the product fails to reach expectations or because the consumer becomes aware of a superior alternative. At this stage, marketing communication should be aimed at reinforcing past decisions by stressing the positive feature of the product or by providing more information to assist its use and application. Buyers don't follow the general decision sequence at all times. The process may vary depending upon the time available, level of perceived risk and the degree of involvement a 
buyer has with the type of product. Lin and Chen (2006) assume that a consumer's purchase behavior under his/her demand confirmation is ensured, rather than discussing how a consumer executes project evaluation and the after purchasing result. Therefore, this paper selects and uses information search intention and purchase intention as major variables that influence consumer purchase decision.

\section{Country-of-Origin}

The country-of-origin (COO) of a product has been defined as "the country of manufacture or assembly" (Bilkey \& Nes, 1982), identified by "made in" or "manufactured in" labels (Nagashima, 1977). However, the growth of multinational companies and the emergence of hybrid products with components sourced from many countries have blurred the accuracy or validity of "made in" or "manufactured in" labels (Ahmed, Johanson, Yang, Chen, Han, \& Boon, 2004), making the identification of COO sometimes very difficult. For example, consumers identify many well-known brands with particular countries, even if the product being evaluated was not manufactured in the firm's country of domicile. Thus, Toyota and Honda products are considered to be Japanese, McDonald's and KFC originated in the U.S..

\section{The Influence of Country-of-Origin Image on a Consumer Purchase Decision}

Consumers make purchase decisions based on a systematic process of acquisition, evaluation and integration of product information or cues. A cue is defined as all informational stimuli available to the consumer before consumption (Ahmed et al., 2004), and can be intrinsic or extrinsic. According to Hong and Wyer (1989), when consumers are presented with the $\mathrm{COO}$ cue together with other cues, such as price and brand, the effects of $\mathrm{COO}$ in their cognitive process can be observed in two ways: the halo effect and the summary construct. When consumers are not familiar with the products of a country, the country image acts as a "halo" that directly affects consumers' beliefs about these products. In contrast, when consumers are familiar with a country's products, a summary construct model operates in which consumers infer a country's image from its product information. Moreover, Papadopoulos and Heslop (1993) point out that, country's image does influence a consumer's purchase decision. Especially, when the country of manufacturing image appears negative, a consumer might have a negative image of that country's product. Therefore, the country-of-origin image does play a very important role when a consumer makes a purchase decision.

\section{Product Knowledge}

Product knowledge plays an important role in the research of consumer behavior, therefore, it is an essential research subject in related fields. Brucks (1985) states that product knowledge is based on memories or known knowledge from consumers. Based on a definition of Brucks about product knowledge, it can be divided into three major categories: subjective knowledge, objective knowledge, and experience-based knowledge. However, Alba and Hutchinson (1987) indicate that product knowledge should contain two parts: expertise and familiarity. Otherwise Scribner and Seungoog (2001) classify product knowledge into three categories: (1) brand knowledge; (2) attribute knowledge; and (3) experience knowledge (Lee, 2007, p. 17).

\section{The Influence of Product Knowledge on a Consumer Purchase Decision}

Research of consumer behavior and product knowledge plays a significant role. During his/her purchasing process, the amount of knowledge consumer has about a product would not only affect his/her information search behavior (Brucks, 1985), but also, at the same time, affect his/her information and 
decision-making processing. Furthermore, it influences the consumer purchasing intention (Lin \& Chen, 2006). The relationship between product knowledge and information search has not yet generated any definite conclusion. Some scholars state that consumers' understanding in product knowledge has a positive correlation to information search quantity, such as Moore and Lehmann (1980), Alba and Hutchinson (1987). Some scholars assert that these two variables have a negative correlation, such as Brucks (1985), Newman and Staelin (1972). Therefore, when scholars face these two different conclusions, they submit another theory, i.e., that product knowledge and information search quantity has a U-shape correlation rather than simply a linear correlation, as Johnson and Russo (1984) assert.

\section{Product Involvement}

Involvement originates from social psychology and the notion of "ego involvement", which refers to the relationship between an individual, an issue or object (Michaelidou \& Dibb, 2006). This conceptualization has been the basis for applying involvement in consumer behavior. The involvement construct became linked to marketing and consumer behavior following Krugman's (1965) conceptualization of involvement with advertising. Since then, and specifically through a period of increasing consumer research activity in the 1980s, attention has focused on the conceptualization and measurement of involvement in relation to "objects" such as a product, message, purchase task, advertising or activity. At the heart of these conceptualizations is the notion of "personal relevance": There is a general agreement that a consumer's level of involvement with an object is determined by the extent to which the product is seen as personally relevant (Zaichkowsky, 1985). Involvement has also been examined in relation to other concepts such as perceived risk, information search, attribute comparison, brand loyalty, retail context, diffusion and opinion leadership.

\section{Classification of Involvement}

The most rigorous attempt to categories definitions of involvement is made by Laaksonen (1997) in a three-category classification: cognitively-based approach, individual-state approach and response-based approach. These categories embrace ideas of Rothschild (1979) who suggests three forms or types of involvement: enduring, situational and response (Michaelidou \& Dibb, 2006, p. 443). Although such variables

have been used to conceptualize and measure involvement, they are widely regarded to be consequences of involvement, rather than involvement per se. This debate of conceptualization is ongoing, although many researchers now favor the enduring and situational perspectives. Enduring involvement (EI): It indicates the perceived personal relevance of an object to an individual. It is motivated by the degree to which the product (or object) relates to the self and/or pleasure received from. Situational involvement (SI): The basic characteristic of this involvement type is that it represents a "mental state" and has nothing to do with cognitive elements such as values and needs. Unlike enduring involvement, SI represents a temporary interest or concern with an object, which has been triggered by a particular cause such as perceived risk.

\section{The Influence of Product Involvement on the Consumer Purchase Decision}

Friedman and Smith (1993) discover in their research concerning service that when consumer selects a service and his/her involvement increases, he/she will search for further more information. Goldsmith and Emmert (1991) report that when involvement level increases, the consumer will search for further information. Petty, Cacioppo and David (1983) discover that high product involvement, brand attitude and purchase intention 
have a much higher correlation than that of low product involvement.

\section{Research Design}

\section{Research Framework}

From the above literature our research model is derived and illustrated in Figure 1.

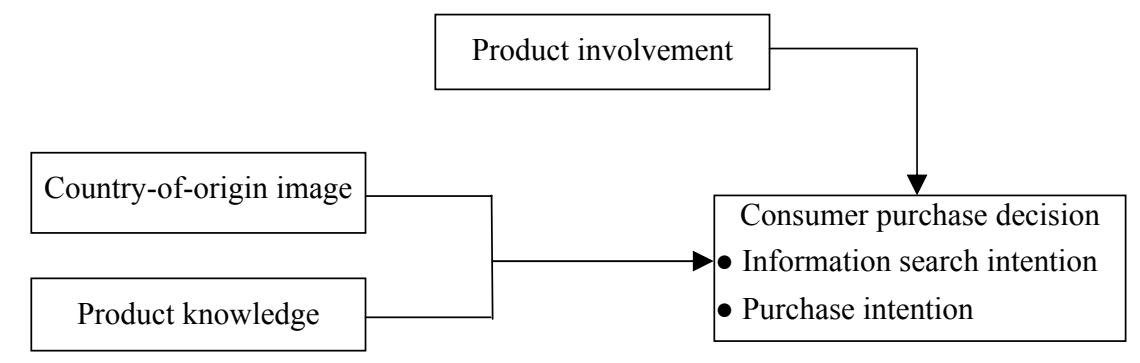

Figure 1. Research model.

\section{Hypothesis Development}

Hong and Wyer (1989) discovered that when a consumer evaluates a foreign country product, he/she will mostly likely adopt a country-of-origin image as the most easy to obtain information. L. A. Manrai and A. K. Manrai (1993) find that when a country brings a rather positive country image to the consumer, then he/she would have a rather high quality perception and overall evaluation to a product manufactured in that country and furthermore would increase his/her purchase intention. Roth and Romeo (1992) state that if a country is known for a rather positive image, and this image is very important to product classification, a consumer would have a higher purchase intention to products from this country. Ahmed et al. (2004) assert that COO does matter when consumers evaluate low-involvement products but, in the presence of other extrinsic cues (price and brand), the impact of $\mathrm{COO}$ is week and brand becomes the determinant factor. Lin and Chen (2006) discover that country-of-origin image has a significantly positive influence on the consumer purchase decision. Based on the above literature, the first hypothesis for this study is developed as follows:

H1: The country-of-origin image asserts a significantly positive impact on the consumer purchase decision.

H1-1: The country-of-origin asserts a significantly positive impact on the consumer information search intention.

H1-2: The country-of-origin asserts a significantly positive impact on the consumer purchase intention.

Moore and Lehmann (1980) discovered that, in their empirical study, consumer product knowledge has a significantly positive impact on his/her effort in information search. Brucks (1985) points out that, during purchase processing, a consumer's knowledge of the product would not only affect his/her search behavior, but also affect his/her information treatment and decision-making processing, and would furthermore, affect his/her purchase intention. Lin and Chen (2006), reports that consumer product knowledge has a significantly positive influence on consumer purchase decision. The second hypothesis for this study is as follows:

H2: Consumer product knowledge has a significantly positive impact on consumer purchase decision.

H2-1: Consumer product knowledge has a significantly positive impact on consumer information search intention.

H2-2: Consumer product knowledge has a significantly positive impact on consumer purchase intention. 
Mitchell (1981) reports in his research that at a higher product involvement level, consumers will aggressively search for relevant information and furthermore evaluate the product. Petty et al. (1983) discover that, with high product involvement, the correlation between brand attitude and purchase intention is significantly higher than that with low product involvement. Neese and Taylor (1994) assert that, in an automobile comparison advertisement with a different information advertisement load, a product of high involvement would have a much more positive influence on advertisement attitude, brand loyalty, and brand attitude, than that with a product of low involvement. Chebat, Charlebois and Gelinas-Chebat (2001) report that consumer under low involvement conditions may reach deeper levels of information processing as long as they are knowledgeable of the product advertised and they perceive low risk in it. Lin and Chen (2006) discover that product involvement has a significantly positive influence on consumer purchase decision. Third hypothesis for this study is inferred as follows:

H3: Product involvement has a significantly positive impact on consumer purchase decision.

H3-1: Product involvement has a significantly positive impact on consumer information search intention.

H3-2: Product involvement has a significantly positive impact on consumer purchase intention.

\section{Operational Definition of Variables}

This study defines operational definition of variables as follows: (1) Country-of-origin image: A consumer's overall recognition to a country-of-origin and perception level on the product quality of a specific product; (2) Product knowledge: A consumer's awareness or understanding level of a specific product; (3) Product involvement: A consumer's subjective self-perception of product importance and his/her involvement level concerning a specific product; (4) Consumer purchase decision: Information search intention: Information search efforts consumer would spend on a specific product; and (5) Consumer purchase intention: The possibility of a consumer's willingness to purchase a specific product.

\section{Research Method}

\section{Product Selection}

The selective product in the present research is "cell phone". Unsaturated and profitable market of this commodity in Iran and huge import lead to select this product. Data were collected via questionnaire.

\section{Country-of-Origin Selection}

Based on a systematic random sampling, 50 respondents were selected and inquired about their cell phones' brand. Fifty eight percent of participants were female and $42 \%$ were male. On the other hand, $44 \%$ of respondents had Sony Ericson and 36\% had Nokia. Consequently, the country-of-origin of these two brands, i.e., Japan, Sweden and Finland were chosen for setting questionnaire. Table 1 shows the frequency of commercial brands of participants' cell phones.

Table 1

Frequency of Respondents Cell Phone's Brands

\begin{tabular}{llllllll}
\hline \multirow{2}{*}{ Gender } & \multicolumn{7}{c}{ Respondents cell phone's brands } \\
\cline { 2 - 7 } & Sony Ericsson & Nokia & LG & HTC & Motorola & Samsung & Siemens \\
\hline Female & 0.26 & 0.20 & 0.02 & 0.02 & 0.00 & 0.08 & 0.00 \\
Male & 0.18 & 0.16 & 0.00 & 0.02 & 0.02 & 0.02 & 0.02 \\
Total & 0.44 & 0.36 & 0.02 & 0.04 & 0.02 & 0.10 & 0.02 \\
\hline
\end{tabular}




\section{Questionnaire Design}

The questionnaire design in this paper includes five major parts, which are: country-of-origin image, product knowledge, product involvement level, and consumer purchase decision (including information search intention and purchase intention), and a respondent's basic information. In order to measure the country image in this study, the perspectives of Martin and Eroglu (1993), and Lin and Chen (2006) are adopted. COO image measurement includes eight dimensions. The questionnaire on product knowledge measurement, which is developed based on referring the studies of Brucks (1985) and Lin and Chen (2006), mainly measures consumer's perception level and memory storage level after-purchase or after-use cell phone. As far as selecting the dimension of product involvement measurement, the personal involvement inventory developed by Zaichkowsky in 1985 is adopted, referring Lin and Chen's (2006) measurement items, this study selects six items to measure the consumer's product involvement level. As far as measuring a consumer's purchase decision, including consumer information search intention and purchase intention, this study mainly takes reference from the Lin and Chen's (2006) study concerning information search intention and items selection. In addition, this study mainly takes reference from Dodds, Monroe and Grewal (1991), Klein, Ettenson and Morris (1998) and Lin and Chen (2006) which concerns measuring purchase intention and item selection. A respondent's basic information includes whether he/she had purchased cell phone, cell phone's brand, gender, age, and educational background. The study use a five-point Likert scale, with scale anchors ranging from "1" (strongly disagree) to "5" (strongly agree), all scale items are listed in the Appendix.

\section{Sampling Target}

Participants were college students. According to Shouli (2007), in every society college students and consumers belong to the middle and high class, and their education, revenue, social status and social interactions make them more involved. Therefore, college students who are in different age ranges with varying income levels were selected as the sample of this research.

\section{Sampling Method and Sample Size}

Selective university is comprised of nine schools, and seventeen majors are taught in that. Totally, 23,420 students study there. According to Krejcie and Morgan's table, sample size was defined 379. Proportional Stratified sampling and systematic random sampling were applied. In the first place, based on Proportional Stratified sampling, sharing and distribution of questionnaires were done relative to the numbers of schools. Afterwards, systematic random sampling was done in front of the college entrance gate to choose the respondents. With regard to the size of sample, 400 questionnaires were distributed, 385 of which were efficient. However, only 379 questionnaires were used based on least size of sample.

\section{Data Collection and Data Analysis Method}

Data collection lasted for five days in June, every time from 8 a.m. to 6 p.m., 400 questionnaires were distributed and collected in front of the entrance gate. SPSS and LISREL software were applied for analysis and comparison of data. Cronbach's $\alpha$ value was used to test the reliability of questionnaire, factor analysis to test construct validity and Pierson's correlation coefficient to investigate the relation between variables. Ultimately, multiple regression analysis was done to test the hypothesis of the research. 


\section{Data Analysis}

\section{Sample Description}

The characteristic features of participants includes: brand of cell phone, gender, age, level of education. Out of 379 samples, 59\% used Nokia and 41\% Sony Ericson; 52\% were male while 48\% were female. The fewest participants belonged to the age range of over 42 which comprised less than $1 \%$ of total. The most participants belonged to the age range of $18-23$, or $53 \%$ of total. Participants between the age ranges of $24-29$ comprised $34 \%$ of the total, while it was $8 \%$ for those between the age ranges of $36-41$. On the other hand, it was verified that $4 \%$ were Ph.D. students, $56 \%$ belonged to B.A. course and $40 \%$ belonged to M.A. course.

\section{Constructs of Research}

One way of analysis process of data includes extracting variables out of raw data. Main variables were measured based on several indices. Scores of variables were defined through arithmetic average, as well measures of central parameter and dispersion were used to provide precise description (see Table 2). In the process of extracting variables out of row data, with regard to the hypotheses of research about consumer information search intention and their purchase intention, three research variables were extracted out of raw data. On the whole, raw achieved data out of 25 questions were changed into 6 variables including: the country-of-origin image, product knowledge, product involvement, information search intention, purchase intention, and consumer purchase decision.

Table 2

Average, Standard Deviation and Correlation Coefficient of Constructs

\begin{tabular}{lllllll}
\hline Variables & 1 & 2 & 3 & 4 & 5 & 6 \\
\hline Country-of-origin image & 1.00 & & & & \\
Product knowledge & 0.268 & 1.00 & & & & \\
Product involvement & 0.250 & 0.414 & 1.00 & & & \\
Information search intention & 0.298 & 0.425 & 0.335 & 1.00 & & \\
Purchase intention & 0.375 & 0.351 & 0.325 & 0.675 & 1.00 & 1.00 \\
Consumer purchase decision & 0.351 & 0.432 & 0.359 & 0.961 & 0.852 & 3.3555 \\
Average & 3.8163 & 3.6364 & 3.3461 & 3.1867 & 3.6933 \\
Standard deviation & 0.57783 & 0.59455 & 0.72905 & 0.94037 & 0.99457 & 0.88508 \\
\hline
\end{tabular}

\section{Reliability and Validity Analysis}

To assess the reliability of questionnaire, Cronbach's $\alpha$ value was applied. To examine that, a pre-test was carried out in sample with 55 respondents and 50 practical questionnaires. The conclusion shows that Cronbach's $\alpha$ value of each variable was more than 0.7 (see Table 3). The least significant reliability for research questionnaires is 0.7 , thus, this questionnaire was recognized reliable.

The content validity and construct validity were used in this paper to examine the validity of the questionnaire. Content validity is performed based on the researcher's professional ability to judge subjectively if the selected scale can measure the researcher's intended-to-measure feature correctly. The dimensions and items explored in this study are based on a relevant theory. This inventory or measuring item was used by many scholars globally. In addition, we carried out a pre-test and did some revision before setting out the questionnaire. 
Therefore, the questionnaire as a measuring tool used in this study should meet the requirement of content validity. This study applies further confirmatory factor analysis to examine the construct validity of this questionnaire. The results are shown in Table 4. This study shows, according to the figures in Table 4, factor loading of questions, except four questions is higher than 0.5. Although, the factor loading of four questions is lower than 0.5 , but are also very close to 0.5 . Therefore, it also means that the questionnaire used in this study performs construct validity. On the other hand, the $t$ value of each question positively surpasses critical value's 1.96 , it can be claimed that at $95 \%$ confidence, questionnaire was valid.

Table 3

Reliability of Questionnaire of Pre-test and Formal Investigation

\begin{tabular}{lll}
\hline Variables & Pre-test Cronbach's alpha value & Formal investigation Cronbach's alpha value \\
\hline Country-of-origin image & 0.86 & 0.83 \\
Product knowledge & 0.79 & 0.70 \\
Product involvement & 0.80 & 0.81 \\
Information search intention & 0.95 & 0.85 \\
Purchase intention & 0.82 & 0.87 \\
Purchase decision & 0.94 & 0.88 \\
Overall questionnaire & 0.93 & 0.88 \\
\hline
\end{tabular}

Table 4

Validity of Formal Questionnaire

\begin{tabular}{|c|c|c|c|}
\hline Variables & Questions & Factor loading & $t$ \\
\hline \multirow[t]{8}{*}{ Country-of-origin image } & 1 & 0.52 & 9.74 \\
\hline & 2 & 0.45 & 8.39 \\
\hline & 3 & 0.56 & 10.69 \\
\hline & 4 & 0.54 & 10.30 \\
\hline & 5 & 0.61 & 11.82 \\
\hline & 6 & 0.69 & 13.89 \\
\hline & 7 & 0.45 & 8.28 \\
\hline & 8 & 0.68 & 13.56 \\
\hline \multirow[t]{5}{*}{ Product knowledge } & 9 & 0.56 & 9.80 \\
\hline & 10 & 0.47 & 8.02 \\
\hline & 11 & 0.68 & 11.99 \\
\hline & 12 & 0.45 & 7.75 \\
\hline & 13 & 0.49 & 8.55 \\
\hline \multirow[t]{6}{*}{ Product involvement } & 14 & 0.43 & 8.25 \\
\hline & 15 & 0.78 & 17.06 \\
\hline & 16 & 0.87 & 19.65 \\
\hline & 17 & 0.53 & 10.48 \\
\hline & 18 & 0.67 & 13.88 \\
\hline & 19 & 0.42 & 8.05 \\
\hline \multirow[t]{6}{*}{ Consumer purchase decision } & 20 & 0.75 & 16.18 \\
\hline & 21 & 0.81 & 18.28 \\
\hline & 22 & 0.77 & 16.99 \\
\hline & 23 & 0.76 & 16.67 \\
\hline & 24 & 0.86 & 18.95 \\
\hline & 25 & 0.86 & 19.00 \\
\hline
\end{tabular}




\section{Correlation Analysis}

Correlation coefficient of Pierson was applied to study the relation between constructs. The results are listed in Table 2 . As it is stated in the table, Pierson coefficients between constructs are significant at $99 \%$ confidence level.

\section{Hypothesis Testing}

To test the hypotheses of the research, three multiple regression equations were used, among which there was one dependant variable and three independent variables. In the first model, the simultaneous effect of three independent variables, i.e., the country-of-origin image, product involvement and product knowledge was investigated on dependant variable, i.e., information search intention. In the second model, the simultaneous effect of three independent variables, i.e., country-of-origin image, product involvement and product knowledge were investigated on consumer purchase intention. In the third model, the simultaneous effect of three variables, namely, country of origin, product involvement and product knowledge were investigated on consumer purchase decision (see Tables 5-7).

Table 5

The Results of Regression Analysis for Dependant and Independent Variables From First Model

\begin{tabular}{|c|c|c|c|c|c|}
\hline \multirow{2}{*}{ Variables } & \multicolumn{2}{|c|}{ Non-standard coefficients } & \multirow{2}{*}{\multicolumn{2}{|c|}{$\begin{array}{l}\text { Standard coefficients } \\
\text { Beta }\end{array}$}} & \multirow{2}{*}{$p$-value } \\
\hline & $B$ & Standard error & & & \\
\hline Constant & -0.383 & 0.347 & & -1.104 & 0.270 \\
\hline Country-of-origin image & 0.282 & 0.077 & 0.147 & 3.663 & 0.000 \\
\hline Product knowledge & 0.492 & 0.080 & 0.311 & 6.168 & 0.000 \\
\hline Product involvement & 0.211 & 0.065 & 0.163 & 3.256 & 0.001 \\
\hline$F=39.146, P=0.000$ & $R=0.488$ & $R^{2}=0.238$ & \multicolumn{3}{|c|}{ Standard error of estimate $=0.82389$} \\
\hline
\end{tabular}

Table 6

The Results of Regression Analysis for Dependant and Independent Variables From Second Model

\begin{tabular}{|c|c|c|c|c|c|}
\hline \multirow{2}{*}{ Variables } & \multicolumn{2}{|c|}{ Non-standard coefficients } & \multirow{2}{*}{\multicolumn{2}{|c|}{$\begin{array}{l}\text { Standard coefficients } \\
\text { Beta }\end{array}$}} & \multirow{2}{*}{$p$-value } \\
\hline & $B$ & Standard error & & & \\
\hline Constant & -0.155 & 0.369 & & -0.419 & 0.675 \\
\hline Country-of-origin image & 0.476 & 0.082 & 0.277 & 5.810 & 0.000 \\
\hline Product knowledge & 0.344 & 0.085 & 0.206 & 4.067 & 0.000 \\
\hline Product involvement & 0.233 & 0.069 & 0.171 & 3.385 & 0.001 \\
\hline$F=37.595, P=0.000$ & $R=0.481$ & $R^{2}=0.231$ & \multicolumn{3}{|c|}{ Standard error of estimate $=0.87552$} \\
\hline
\end{tabular}

Table 7

The Results of Regression Analysis for Dependant and Independent Variables From Third Model

\begin{tabular}{|c|c|c|c|c|c|}
\hline \multirow{2}{*}{ Variables } & \multicolumn{2}{|c|}{ Non-standard coefficients } & \multicolumn{2}{|c|}{$\underline{\text { Standard coefficients }}$} & \multirow{2}{*}{$p$-value } \\
\hline & $B$ & Standard error & Beta & & \\
\hline Constant & -0.307 & 0.319 & & -0.962 & 0.337 \\
\hline Country-of-origin image & 0.347 & 0.071 & 0.227 & 4.892 & 0.000 \\
\hline Product knowledge & 0.443 & 0.073 & 0.297 & 6.036 & 0.000 \\
\hline Product involvement & 0.218 & 0.059 & 0.180 & 3.664 & 0.000 \\
\hline$F=46.836, P=0.000$ & $R=0.522$ & $R^{2}=0.273$ & \multicolumn{3}{|c|}{ Standard error of estimate $=0.75790$} \\
\hline
\end{tabular}


(1) Testing of information search intention

- The impact of country-of-origin image on information search intention: Based on the testing result from model 1 in Table 5, explanatory power of the first model is $0.238, p$-value which defines good fitness is $0.000<$ 0.05 , which shows it reaches statistical significant. It also means country-of-origin image has a significantly impact on information search intention, and $t$ value is 3.663. Since $t$ value positively surpasses critical value's 2.58 , it can be claimed that at $99 \%$ confidence level, the country-of-origin has a significantly positive impact on information search intention. Therefore, H1-1 is strongly supported;

- The impact of product knowledge on information search intention: According to the testing result from model 1 in Table 5, $p$-value which defines good fitness is $0.000<0.05$, which shows it reaches statistical significant. It also means product knowledge has a significantly impact on information search intention, and $t$ value is 6.168 . Since $t$ value positively surpasses critical value's 2.58 , it can be claimed that at $99 \%$ confidence level, the product knowledge has a significantly positive impact on information search intention. Therefore, H2-1 is strongly supported;

- The impact of product involvement on information search intention: According to the testing result from model 1 in Table $5, p$-value which defines good fitness is $0.001<0.05$, which shows it reaches statistical significant. It also means product involvement has a significantly impact on information search intention, and $t$ value is 3.256. Since $t$ value positively surpasses critical value's 2.58 , it can be claimed that at $99 \%$ confidence level, the product involvement has a significantly positive impact on information search intention. Therefore, H3-1 is strongly supported.

(2) Testing of purchase intention

- The impact of country-of-origin image on purchase intention: Based on the testing result from model 2 in Table 6 , explanatory power of the first model is 0.231 , $p$-value which defines good fitness is $0.000<0.05$, which shows it reaches statistical significant. It also means country-of-origin image has a significantly impact on purchase intention, and $t$ value is 5.810. Since $t$ value positively surpasses critical value's 2.58 , it can be claimed that at $99 \%$ confidence level, the country of origin has a significantly positive impact on purchase intention. Therefore, H1-2 is strongly supported;

- The impact of product knowledge on purchase intention: According to the testing result from model 2 in Table $6, p$-value which defines good fitness is $0.000<0.05$, which shows it reaches statistical significant. It also means product knowledge has a significantly impact on purchase intention, and $t$ value is 4.067 . Since $t$ value positively surpasses critical value's 2.58 , it can be claimed that at $99 \%$ confidence level, the product knowledge has a significantly positive impact on purchase intention. Therefore, H2-2 is strongly supported;

- The impact of product involvement on purchase intention: According to the testing result from model 2 in Table $6, p$-value which defines good fitness is $0.001<0.05$, which shows it reaches statistical significant. It also means product involvement has a significantly impact on purchase intention, and $t$ value is 3.385 . Since $t$ value positively surpasses critical value's 2.58 , it can be claimed that at $99 \%$ confidence level, the product involvement has a significantly positive impact on purchase intention. Therefore, H3-2 is strongly supported.

(3) Testing of consumer purchase decision

- The impact of country-of-origin image on consumer purchase decision: Based on the testing result from model 3 in Table 7, explanatory power of the first model is 0.273 , $p$-value which defines good fitness is $0.000<0.05$, 
which shows it reaches statistical significant. It also means country-of-origin image has a significantly impact on purchase decision, and $t$ value is 4.892. Since $t$ value positively surpasses critical value's 2.58 , it can be claimed that at $99 \%$ confidence level, the country of origin has a significantly positive impact on purchase decision. Therefore, $\mathrm{H} 1$ is strongly supported;

- The impact of product knowledge on consumer purchase decision: According to the testing result from model 3 in Table 7, $p$-value which defines good fitness is $0.000<0.05$, which shows it reaches statistical significant. It also means product knowledge has a significantly impact on purchase decision, and $t$ value is 6.036 . Since $t$ value positively surpasses critical value's 2.58 , it can be claimed that at $99 \%$ confidence level, the product knowledge has a significantly positive impact on purchase decision. Therefore, $\mathrm{H} 2$ is strongly supported;

- The impact of product involvement on consumer purchase decision: According to the testing result from model 3 in Table 7, $p$-value which defines good fitness is $0.000<0.05$, which shows it reaches statistical significant. It also means product involvement has a significantly impact on purchase decision, and $t$ value is 3.664. Since $t$ value positively surpasses critical value's 2.58 , it can be claimed that at $99 \%$ confidence level, the product involvement has a significantly positive impact on purchase decision. Therefore, H3 is strongly supported.

\section{Conclusions and Managerial Implications}

\section{Conclusions}

The verification of the hypotheses in this paper leads to three conclusions: (1) Country-of-origin image has a significantly positive influence on consumer purchase decision; (2) A consumer's product knowledge has a significantly positive influence on consumer purchase decision; (3) Product involvement has a significantly positive influence on consumer purchase decision.

\section{Managerial Implications}

The present research scrutinizes the structure of consumer purchase decision. In comparison with previous researches, it investigates purchase intention and information search intention more comprehensively. Furthermore, this research highlights that having knowledge about products has a positive and significant relation with information search intention. Considering the fact that previous researchers had achieved various results about the relationship between these two variables, findings of the present study can clarify part of previous ambiguities.

- WTO facilitates the trend of seeing and enjoying different products of different countries. So that companies encounter competitive strategies of many countries. With respect to the proved impact of country-of-origin image on consumers' decision making, it is suggested that marketers consider this issue besides brand image, afterwards, they can use the most appropriate competitive strategy. If country-of-origin image is positive, marketers should take advantage of it and include the features of country-of-origin image in their advertising strategies. In case country-of-origin implies a negative image, it is reasonable to put more emphasis on the product and marketing activities focus on advertising the features of product to attract more consumers and deviate consumers' mind from country-of-origin;

- Due to the fact that consumer's product knowledge leaves a positive effect on consumers' decision, it is recommend that companies would benefit by making more effort to better inform consumers about their products. Apart from the influence on purchase intention, consumers equipped with higher levels of knowledge about a specific product are less likely to be apprehensive about using it. The informing process can be achieved using 
various media channels;

- Involvement has a positive effect on consumers' purchase intention. Marketers who willing to increase profitability of companies via increasing consumer purchase intention should pay attention to product involvement factor in order to maintain consumer involved. So it is recommended that marketing managers investigate the involvement profile of their consumers. These kinds of investigations can be useful to create differentiation and developing competitive strategies.

\section{Limitations of the Study and Future Studies}

\section{Limitations of the Study}

Despite of achieving concrete conclusions, the present research bears some limitations, too. However, these limitations can create opportunities for further research. They are as follows:

- Merely and only one university was selected as a representative population, and samples were homogenous, young, educated and well-informed about product. Possibly, such sample won't be indicative of general consumers of cell phone in the society. Consequently, generalization is subject to limitation;

- The present study was carried out based on one product, i.e., cell phone. Although concrete conclusions were made, it may not be generalized to other products' categories.

\section{Future Studies}

- As the main features of the present sample were being young, homogenous, and educated, it is suggested to select more heterogeneous samples for further research;

- Other researchers can choose products with high involvement and low involvement and compare these two, or they can search about other kinds of products' categories;

- Since product knowledge and involvement are multi-dimensional variables and every one of these variables can be associated with consumer purchase decisions, it is recommended to examine these dimensions and their relation to purchase decisions;

- Further, researchers can investigate why some people have high involvement with a specific product while others have low involvement.

\section{References}

Ahmed, Z. U., Johanson, J. P., Yang, X., Chen, K. F., Han, S. T., \& Boon, L. C. (2004). Does country of origin matter for low-involvement products? International Marketing Review, 21, 102-120.

Alba, J., \& Hutchinson, J. W. (1987). Dimensions of consumer expertise. Consumer Research, 13, 411-54.

Bilkey, W. J., \& Nes, E. (1982). Country of origin effect on product evaluation. International Business Studies, 8, 89-99.

Brucks, M. (1985). The effect of product class knowledge on information search behavior. Consumer Research, 12, 1-16.

Chebat, J. Ch., Charlebois, M., \& Gelinas-Chebat, C. (2001). What makes open vs. closed conclusion advertisements more persuasive? The moderating role of prior knowledge and involvement. Business Research, 93-102.

Dodds, B. K., Monroe, K. B., \& Grewal, D. (1991). Effect of price, brands and store information on buyers' product evaluation. Marketing Research, 28, 307-19.

Fill, Ch. (1999). Marketing communications: Contexts, content and strategies (2nd ed.). London: Prentice Hall.

Friedman, M. L., \& Smith, L. (1993). Consumer evaluation process in a service setting. Service Marketing, 7, 47-61.

Goldsmith, R. E., \& Emmert, J. (1991). Measuring product category involvement: A multitrait-multimethod study. Business Research, 23, 363-71. 
Hong, S., \& Wyer, R. S. Jr. (1989). Effects of country of origin and product attribute information on product evaluation: An information processing perspective. Consumer Research, 16, 175-85.

Johnson, E. J., \& Russo, J. E. (1984). Product familiarity and learning new information. Consumer Research, 11, 542-50.

Kapferer, J. N., \& Laurent, G. (1985). Consumer involvement profiles: A new practical approach to consumer involvement. Advertising Research, 25, 48-56.

Klein, J. R., Ettenson, R., \& Morris, M. D. (1998). The animosity model of foreign product purchase. Marketing, 62, 89-100.

Krugman, H. E. (1965). The impact of television advertising learning without involvement. Public Opinion Quarterly, $29,349-56$.

Lee, S. (2007). Consumer response to online recommendation systems and the moderating role of product knowledge and product involvement (Master dissertation, Michigan State University).

Lin, L. Y., \& Chen, Ch. Sh. (2006). The influence of the country-of-origin image, product knowledge and product involvement on consumer purchase decisions: An empirical study of insurance and catering services in Taiwan. Consumer Marketing, 23, 248-265.

Manrai, L. A., \& Manrai, A. K. (1993). Positioning European country as brands in a perceptual map: An empirical study of determinants of consumer perception and preference. Euro Marketing, 2, 101-29.

Martin, I. M., \& Eroglu, S. (1993). Measuring a multidimensional construct: Country image. Business Research, 28, 191-210.

Michaelidou, N., \& Dibb, S. (2006). Product involvement: An application in clothing. Consumer Behavior, 5, 442-53.

Mitchell, A. A. (1981). Dimensions of advertising involvement. Advances in Consumer Research, 8, 25-30

Moore, W. L., \& Lehmann, D. R. (1980). Individual differences in search behavior for a nondurable. Consumer Research, 7 , 296-307.

Nagashima, A. (1977). A comparative "Made in" product image survey among Japanese businessmen. Marketing, 41, 95-100.

Neese, W. T., \& Taylor, R. D. (1994). Verbal strategies for indirect comparative advertising. Advertising Research, 34, 56-69.

Newman, J. W., \& Staelin, R. (1972). Pre-purchase information seeking for new cars and major household appliances. Marketing Research, 9, 249-57.

Papadopoulos, N., \& Heslop, L. A. (1993). Product-country image: Impact and role in international marketing. London: International Business Press.

Petty, R. E., Cacioppo, J. T., \& David, S. (1983). Central and peripheral routes to advertisements effectiveness: The moderating role of involvement. Consumer Research, 10, 135-46.

Roth, M. S., \& Romeo, J. B. (1992). Matching product and country image perceptions: A framework for managing country-of-origin effects. International Business Studies, 23, 477-97.

Shouli, R. (2007). Exploring the decision-making process of men's branded underwear consumers (Master dissertation, North Carolina State University).

Zaichkowsky, J. L. (1985). Measuring the involvement construct. Consumer Research, 12, 341-52.

\section{Appendix}

Country-of-Origin Image's Measuring Items:

(1) The level of economical development of this country is high;

(2) The level of democratic politics of this country is high;

(3) The level of industrialization of this country is high;

(4) The standards of living of this country are high;

(5) The level of technically advanced of this country is high;

(6) The product quality of this country is high level;

(7) It is great to have the product of this country;

(8) The product of this country is reliable.

Product Knowledge's Measuring Items:

(1) The level what I know about this product;

(2) The willingness I want to understand this product actively;

(3) The level what I actually stored in my memory about this product's information;

(4) The level what I can discriminate the difference of product and brand of different product firms;

(5) After purchase and use of this product, the accumulated level what I know about this product. 
Product Involvement's Measuring Items:

(1) This product is what I want for me;

(2) This product is very important for me;

(3) This product is worthy for me;

(4) This product is what I need for me;

(5) For me, this product I will take care and think more and more;

(6) This product is helpful for me.

Information Search Intention's Measuring Items:

(1) I like to read the information about this product;

(2) I will watch out the advertising and report about this product;

(3) I will consult the questions and felling to the people who had purchased this product;

(4) I had got the main information (for example, country-of-origin or price etc.) about this product from advertising, but I will search the other information about this product.

Purchase Intention's Measuring Items:

(1) The possibility I will buy this product;

(2) The possibility I recommend to other people who also want to buy this product. 